\title{
PENGARUH PELAYANAN KARYAWAN TERHADAP KEPUASAN NASABAH PADA PT. PEGADAIAN (PERSERO) SYARIAH UNIT TANAH MERAH CABANG PEGADAIAN SOEBRANTAS
}

\author{
Zulkifli* \\ *Fakultas Agama Islam (FAI) Universitas Islam Riau (UIR) Pekanbaru \\ Jl. Kaharuddin Nasution No. 113 Perhentian marpoyan Pekanbaru 28284 \\ e-mail : zulkifli_rusby@fis.uir.ac.id
}

\begin{abstract}
Abstrak : Penelitian ini dilatarbelakangi oleh banyaknya lembaga keuangan syariah yang mengatur keuangan masyarakat salah satunya adalah Pegadaian Syariah. Pelayanan merupakan syarat utama bagi kelangsungan hidup bagi suatu perusahaan. Dengan pelayanan yang baik serta kenyamanan yang diberikan kepada nasabah dapat menentukan laju pertumbuhan suatu perusahaan. Rumusan masalah dalam penelitian ini adalah bagaimanakah pengaruh pelayanan karyawan terhadap kepuasan nasabah pada PT. Pegadaian Syariah Unit Tanah Merah Cabang Pegadaian Soebrantas. Tujuan penelitian ini untuk mengetahui pengaruh pelayanan karyawan terhadap kepuasan nasabah. Metode penelitian adalah jenis penilitian kausalitas. Sumber data yang digunakan dalam penelitian ini data primer dan data sekunder. Populasi dalam penelitian ini adalah seluruh nasabah PT. Pegadaian Syariah Unit Tanah Merah berjumlah 1,436 orang. Teknik pengambilan sampel dalam penelitian ini adalah menggunakan random sampling yaitu mengambil secara acak sebanyak 94 orang. Sedangkan teknik pengumpulan data yang digunakan adalah angket dan dokumentasi. Untuk menganalisa data digunakan metode deskriptif kuantitatif. Dalam menganalisa data kuantitatif digunakan analisis regresi linier sederhana dimana proses perhitungan menggunakan SPSS For windows Versi 16.0. Hasil penelitian diketahui dari hasil uji parsial terdapat pengaruh yang signifikan antara pelayanan karyawan terhadap kepuasan nasabah. Ini diketahui dari tingginya tingkat signifikan sebesar 11,417 dan diketahui nilai koefisien korelasi sebesar 0,766 atau $76.6 \%$ sehingga memiliki hubungan yang kuat. Kesimpulan terdapat kontribusi antara pelayanan karyawan terhadap kepuasan nasabah. Diketahui besaran nilai koefisen determinasi sebesar 0,586 atau 58,6\% dan sisanya 41,4\% tidak termasuk dalam penelitian ini, jadi pengaruh pelayanan karyawan terhadap kepuasan nasabah sehingga memiliki hubungan yang kuat.
\end{abstract}

Kata Kunci : Pelayanan, Karyawan, Nasabah, Pegadaian Syariah. 


\section{PENDAHULUAN}

Pegadaian Syariah merupakan pemberian jasa pinjaman untuk menahan harta atau harta tetap hak milik nasabah yang ditahan yang menggunakan sistem gadai dengan menahan sebagian harta yang digadaikan untuk jaminan atas pinjaman uang dan tidak menentukan tarif jasa dari besar uang pinjaman. Harta yang ditahan memiliki nilai ekonomis dengan pihak penahan memperoleh jaminan untuk mengambil kembali harta titipan nasabah dapat diambil dengan jangka waktu tertentu. Dalam hukum perdata, hak gadai hanya berlaku pada benda bergerak sedangkan dalam hukum Islam, gadai berlaku pada seluruh harta, baik harta yang bergerak maupun yang tidak bergerak (Muhammad, 2008).

Pada dasarnya lembaga pegadaian syariah dalam menjalankan operasionalnya berpegang kepada prinsip-prinsip syariah. Pegadaian syariah memiliki karakteristik seperti tidak memungut bunga dalam berbentuk riba, menetapkan uang sebagai alat tukar bukan sebagai komunitas yang diperdagangkan dalam melakukan bisnis untuk memperoleh imbalan atas jasa atau bagi hasil. Hukum gadai syariah dalam hal ini memenuhi prinsip-prinsip syariah berpegang kepada DSN-MUI No, 25/DSNMUI/III/2002 tanggal 26 juli 2002 tentang gadai menyatakan bahwa pinjaman dengan menggadaikan barang untuk jaminan hutang dalam bentuk gadai (Andri Soemitra, 2010: 388).

Pelayanan adalah tempat berkumpulnya uang dan pekerjaan. Tanpa pelanggan, perusahaan tidak punya apa-apa perusahaanlah yang bergantung pada pelanggan dan untuk pelangganlah kita bekerja, karena pelanggan sumber uang dan pekerjaan. Pelayanan dan kepuasan pelanggan merupakan hal utama dalam perusahaan karena tanpa pelanggan, perusahaan tidak akan ada. Asset perusahaan sangat kecil nilainya tanpa keberadaan pelanggan. Karena itu tugas utama perusahaan adalah penarik dan mempertahankan pelanggan. Pelanggan ditarik dengan tawaran yang lebih kompetitif dan dipertahankan dengan memberikan kepuasan (Nina Rahmayanty, 2010: 5).

Mempertahankan pelanggan lebih mudah dibandingkan mencari pelanggan yang baru karena mencari pelanggan yang baru lebih sulit, karyawan perlu bekerja keras dan membutuhkan pengorbanan yang besar dari segi finansial pemasaran dan membutuhkan tenaga pemasaran yang berjumlah banyak maupun dari segi waktu pelayanan dengan proses yang cukup lama dan harus beberapa kali melalui upaya mencari hubungan dan penarik hati calon pelanggan dengan membentuk suatu pencitraan yang positif yang membutuhkan kreativitas tinggi melalui promosi perkenalanan produk, presentasi produk, penyebaran brosur, acara promosi penjualan dan iklan yang membutuhkan biaya sangat besar agar dapat meyakinkan di mata pelanggan, percaya akan citra produk atau perusahaan bernilai baik (Nina Rahmayanty, 2010: 4).

Islam Mengajarkan bahwa dalam memberikan layanan dari usaha yang dijalankan baik itu berupa barang atau jasa jangan memberikan yang buruk atau tidak berkualitas, melainkan berikanlah yang berkualitas kepada orang lain. Selain itu, kita juga harus berlaku lemah lembut kepada orang lain.

Dalam Al-Qur'an juga dijelaskan tentang berlaku lemah lembut kepada sesama (Q.S Ali Imran: 159):
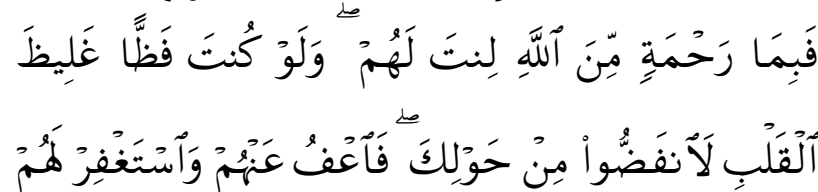

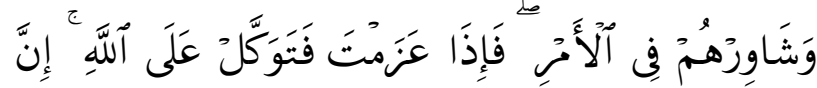

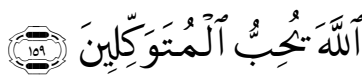

Artinya: Maka disebabkan rahmat dari Allahlah kamu berlaku lemah lembut terhadap 
mereka sekiranya kamu bersikap keras yang berhati kasar, tentulah mereka menjauhkan diri dari sekelilingmu. Karena itu maafkanlah mereka, mohonkanlah ampun bagi mereka, dan bermusyawarahlah dengan mereka dalam urusan itu. Kemudian apalah kamu telah membulatkan tekad, maka bertawaklah kepada Allah. Sesungguhnya Allah menyukai orang-orang yang bertawakal kepada-nya (Depertemen Agama RI, 2006).

\section{TINJAUAN PUSTAKA \\ Teori Pelayanan}

Anggawirya, Erhans, dan Audi (2012: 41), secara etimologi, layanan adalah perbuatan menyediakan segala apa yang diperlukan orang lain. Definisi tersebut mengidentifikasikan bahwa jasa adalah suatu aktifitas. Aktifitas layanan yang tidak hanya sebatas memenuhi kebutuhan pemakai layanan. Meski ada nilai tambahan pada aktifitas tersebut. Kemudian, penciptaan nilai bagi kepuasan pelanggan akan menjadi sebuah "Pekerjaan rumah" bagi para pembisnis.

Pengukuran kinerja pelayanan dapat dilakukan dengan menggunakan instrumen pengukuran kinerja pelayanan yang telah dikembangkan oleh Zaithaml, Parasuraman dan Berry dalam buku mereka yang berjudul, Delivering Quality Service. Menurut mereka (Zeithaml, Parasuraman dan Berry, 1990), ada sepuluh indikator kinerja pelayanan yaitu (Ratminto, 2005: 182): (a) Ketampakan fisik (Tangible), (b). Reliabilitas (Reliability),

(c).Responsivitas

(Responsiveness) , (d). Kompetensi (Competence), (e). Kesopanan (Courtessy), (f). Kredibilitas (Credibility), (g). Keamanan (Security), (h). Akses (Access), (i). Komunikasi (Communication), (j) Pengertian (Understanding the customer)

Ada beberapa karakter yang dimiliki oleh petugas dalam melakukan pelayanan kepada nasabah, di antaranya adalah (Nur Rianto, 2010: 209):

(a) Tidak melakukan tercela. (b) Memegang teguh amanah. (c) Menjaga nama baik perusahaan dan nasabah. (d) Beriman dan mempunyai rasa tanggung jawab moral (f) Sabar tapi tegas dalam menghadapi permasalahan, seperti keluhan nasabah.(g) Memilih integritas, Artinya bertindak jujur dan benar. (h) Manners, artinya tidak egois, disiplin dan tidak kasar.

Dalam proses pelayanan ada tiga hal yang penting yang harus diperhatikan, yaitu (Nur Rianto, 2010: 214):(a) Penyediaan layanan adalah pihak yang dapat memberikan suatu layanan tertentu kepada konsumen, baik berupa layanan dalam bentuk penyediaan dan penyerahan barang atau jasa pelayanan. (b) Penerimaan pelayanan adalah mereka yang disebut sebagai konsumen atau pelanggan yang menerima pelayanan dari penyediaan layanan. (c) Jenis layanan yang dapat diberikan oleh penyedian layanan kepada pihak yang membutuhkan layanan terdiri dari berbagai macam, antara lain berupa layanan yang berkaitan dengan: Pemberian jasa-jasa saja. (2) Layanan yang berkaitan dengan penyediaan dan distribusi barang-barang saja. (3) Layanan yang berkaitan dengan kedua-duanya.

\section{Faktor-faktor Mempengaruh Pelayanan}

Menurut Kennedy dan Young dalam Supranto ada beberapa pengukuran kepuasan pelanggan di bidang jasa sebagai berikut (Ahmadi, 2015: 26): (a) Availability of support (keberadaan pendukung) Yaitu sebagai tingkatan untuk dimana pelanggan dapat kontak dengan pemberi jasa, atau pelanggan dapat menghubungi penghasil jasa, dengan kata lain karyawan dapat mengetahui kebutuhan nasabah, (b) Responsiveness of support (ketanggapan pendukung) Yaitu sebagai tingkatan untuk nama pemberi jasa bereaksi cepat dan tepat terhadap permintaan pelanggan. Artinya bagaimana reaksi karyawan terhadap kebutuhan nasabah.

\section{Kualitas Pelayanan dalam Perspektif Islam}

Konsep Islam mengajarkan bahwa dalam memberikan layanan dari usaha yang dijalankan baik itu berupa barang atau jasa 
jangan memberikan yang buruk atau tidak berkualitas, melainkan berikanlah yang berkualitas kepada orang lain. Selain itu, kita juga harus berlaku lemah lembut kepada orang lain.

Dalam Al-Qur'an juga dijelaskan tentang berlaku lemah lembut kepada sesama (Q.S Ali Imran: 159):

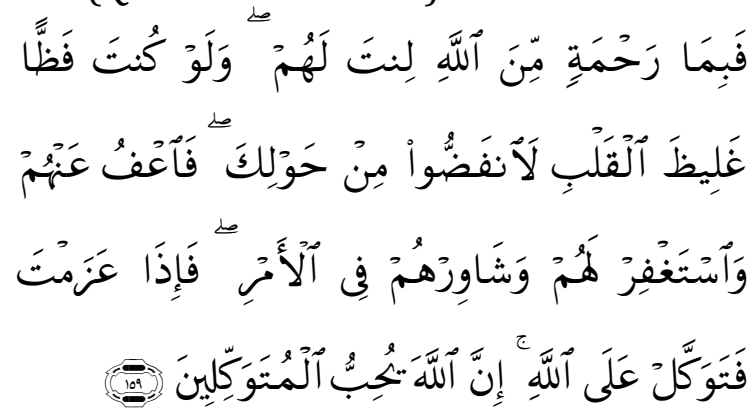

Artinya: Maka disebabkan rahmat dari Allah-lah kamu berlaku lemah lembut terhadap mereka sekiranya kamu bersikap keras yang berhati kasar, tentulah mereka menjauhkan diri dari sekelilingmu. Karena itu maafkanlah mereka, mohonkanlah ampun bagi mereka, dan bermusyawarahlah dengan mereka dalam urusan itu. Kemudian apalah kamu telah membulatkan tekad, maka bertawaklah kepada Allah. Sesungguhnya Allah menyukai orang-orang yang bertawakal kepada-nya (Depertemen Agama RI, 2006).

Dalam Shohih Bukhari 'Memberi kemudahan dan kelapangan ketika membeli, menjual, dan siapa saja yang meminta haknya, maka mintalah dengan cara yang baik'. Dari Jabir bin 'Abdillah, Rasulullah shallallahu 'alaihi wa sallam bersabda,

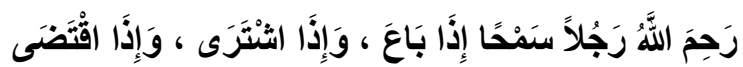

"Semoga Allah merahmati seseorang yang bersikap mudah ketika menjual, ketika membeli dan ketika menagih haknya (utangnya)." (HR. Bukhari no. 2076)

\section{Kepuasan Nasabah}

Kepuasan nasabah semakin di yakini sebagai kunci sukses pemasaran jasa. Oleh karena itu, memperoleh kepercayaan nasabah di warnai oleh fenomena persaingan yang makin ketat dalam era kedaulatan konsumen ini. seiring dengan semakin ketatnya persaingan dalam sektor perbankan menimbulkan pertanyaan tentang cara-cara yang bisa memberikan kepuasan yang sempurna bagi setiap nasabah (Imam Wahjono, 2009: 179).

Jika nilai bagi pelanggan adalah kenyamanan maka kepuasan akan datang apabila pelayanan yang diperoleh benarbenar dapat membuat konsumen tersebut terasa nyaman. Kalau nilai dari pelanggan akan puas kepada produsen yang memberikan harga yang pling kompetitif. Jika nilai dalam perbankan bagi pelanggan adalah kemudahan bertransaksi, maka kepuasan pelanggan akan didapat pada perusahaan yang mampu memberikan kemudahan lebih dalam bertransaksi financial yang akan dialakukan. Atau jika nilai bagi nasabah adalah tingakat return, maka tingkat return (kembali) yang tinggilah yang mampu memberikan kepuasan baginya.

\section{Pegadaian Syariah}

Pegadaian Syariah atau rahn adalah semacam jaminan utang atau gadai. Rahn merupakan sesutu sistim jaminan utang dengan barang yang kita miliki dimana uang dimungkinkan bisa dibayar dengannya. Rahn juga bisa diartikan menahan salah satu harta benda milik si penjamin sebagai jaminan atas pinjaman yang diterimanya. Barang yang dijamin tersebut memiliki nilai ekonomis dan pihak yang menahan itu memperoleh jaminan untuk dapat mengambil kembali seluruh atau sebagian piutangnya.

Rahn juga yaitu perjanjian penyerahan barang atau harta anda sebagai jaminan berdasarkan hukum gadai berupa emas, perhiasan kendaraan, atau barang bergerak lainnya yang terbentuknya pegadaian syariah di Indonesia, yaitu yang bekerjasama dengan Perum pegadaian yang membentu Unit Layanan Gadai Syariah (ULGS). 


\section{Dasar Hukum Pegadaian Syariah}

Pegadaian Syariah merupakan lembaga keuangan syariah dengan sistem gadai yang berlandaskan pada prinsipprinsip ke Islaman.

Payung hukum gadai syariah dalam hal pemenuhan prinsip-prinsip syariah berpegang pada fatwa DSN-MUI No.25/DSNMUI/III/2002 tanggal 26 Juni 2002 yang menyatakan bahwa pinjaman dengan menggadaikan barang sebagai jaminan utang dalam bentuk rahn diperolehkan. Adapun dalam aspek kelembagaan tetap menginduk kepada PP No. 10 tahun 1990 tanggal 10 April 1990 (Cholil Nafis, 2012: 217).

\section{Rukun dan Syarat-syarat Gadai Syariah}

Dalam fikih empat mazhab (fiqh almadzahib al-arba'ah) diungkapkan rukun gadai sebagai berikut. a) Aqid (orang yang berakad) Aqid adalah orang yang melakukan akad yang meliputi 2 (dua) arah, yaitu (a) Rahin (orang yang menggadaikan barangnya), dan (b) Martahin (orang yang berpiutang dan menerima barang gadai), atau penerima gadai. Hal dimaksud, yang didasari oleh shighat, yaitu ucapan berupa ijab qabul (serah-terima antara pegadaian dengan penerima gadai). Untuk melaksanakan akad Rahn yang memenuhi kriteria syariat Islam, sehingga akad yang dibuat oleh 2 (dua) pihak atau lebih harus memenuhi beberapa rukun dan syarat (Zainuddin, 2008: 20). b) Ma'qud 'alaih (barang yang diakadkan) Ma;qud 'alaih meliputi 2 (dua) hal, yaitu (a) Marhun (barang yang digadaikan), dan (b) Marhun bihi (dain), atau utang yang karenanya diadakan akad rahn. Namun demikian, ulama fikih berbeda pendapat mengenai masuknya shighat sebagai rukun dari terjadinya ranh. Ulama mazhab hanafi berpendapat bahwa shighat tidak termasuk sebagai rukun rahn, melainkan ijab (pernyataan menyerahkan barang sebagai agunan bagi pemilik barang agunan tersebut) (Zainuddin, 2008: 21).

\section{Syarat-syarat Gadai Syariah}

Selain rukun yang harus terpenuhi dalam transaksi gadai, maka dipersyaratkan juga syarat. Syarat-syarat gadai dimaksud, terdiri atas: (a) Shighat, (b) pihak-pihak yang berakad cakap menurut hukum, (c) utang (Marhun bih), dan (d) Marhun. Keempat syarat dimaksud, diuraikan sebagai berikut. (Zainuddin, 2008: 21).

\section{Landasan Konsep Pegadaian Syariah}

Sebagaimana halnya Institusikan yang berlebel syariah, maka Landasan konsep Pegadaian Syariah juga mengacu kepada Syariah Islam yang bersumber dari Al-Qur'an dan Hadits nabi Saw (Habiburrahim 2012: 220). Al - Qur'an Artinya:Jika kamu dalam perjalanan (dan bermuamalah tidak secara tunai) sedang kamu tidak memperoleh seorang penulis, maka hendaklah ada barang tanggungan yang di pegang (oleh yang berhutanag). akan tetapi jika sebagian kamu Mempercai sebagian yang lain, maka hendaklah yang dipercayai itu menunaikan amanatnya (Untung) dan hendak ia bertakwa kepada Allah tuhannya; dan janganlah kamu (para saksi) menyembunyikan persaksian. Dan barang siapa yang menyembunyikannya, maka sesungguhny ia adalah yang berdosa hatinya; dan Allah maha mengetahui apa yang kamu kerjakan.(QS.Al-Baqarah:283).

Hadist Nabi Saw

Aisyah berkata bahwa Rasulullah Saw pernah membeli bahan makanan dari seorang Yahudi menggadaikan kepadanya baju besi beliau. (HR.Bukhari dan Muslim) Abu Hurairah r.a berkata bahwa Nabi Saw bersabda, "tidak terlepas dari kepemilikkan barang gadai dari pemilik yang menggadaikannya. Ia memperoleh manfaat dan menanggung resikonya" (HR.AsySyafit'i, Daraquthni dan Ibnu Majah) dan Ijma' Ulama Di samping dalil - dalil di atas, para ulama telah sepakat memperoleh akad rahn (Cholis Nafis, 2012: 222). 
Tabel. 1

Perbedaan Teknis Pegadaian Konvensiaonal-Pegadaian Syariah

\begin{tabular}{|l|l|}
\hline \multicolumn{1}{|c|}{ Pegadaian Konvensional } & \multicolumn{1}{|c|}{ Pegadaian Syariah } \\
\hline $\begin{array}{l}\text { Biaya administrasi menurut } \\
\text { prosentase berdasarkan golongan } \\
\text { barang }\end{array}$ & $\begin{array}{l}\text { Biaya administrasi menurut } \\
\text { ketetapan berdasarkan golongan } \\
\text { barang }\end{array}$ \\
\hline 1 hari dihitung 15 hari & 1 hari dihitung 10 hari \\
\hline $\begin{array}{l}\text { Sewa modal berdasarkan uang } \\
\text { pinjaman }\end{array}$ & $\begin{array}{l}\text { Jasa simpanan berdasarkan } \\
\text { taksiran }\end{array}$ \\
\hline $\begin{array}{l}\text { Bila lama pengembalian pinjaman } \\
\text { lebih dari perjanjian barang gadai } \\
\text { dilelangkan kepada masyarakat }\end{array}$ & $\begin{array}{l}\text { Bila lama pengembalian pinjaman } \\
\text { melebihi akad maka barang gadai } \\
\text { nasabah dijual kepada masyarakat }\end{array}$ \\
\hline Penggolongan nasabah: P-N-I-D-L & Penggolongan nasabah: P-N-I-D-L \\
\hline $\begin{array}{l}\text { Sewa modal di hitung dengan: } \\
\text { prosentase X Uang pinjaman (UP) }\end{array}$ & $\begin{array}{l}\text { Jasa simpanan dihitung dengan } \\
\text { konstanta X Taksiran }\end{array}$ \\
\hline Maksimal jangkah waktu 4 bulan & Maksimal jangka waktu 4 bulan \\
\hline $\begin{array}{l}\text { Uang kelebihan (UK) = hasil lelang } \\
\text { - (uang pinjaman }+ \text { sewa modal }+ \\
\text { biaya lelang) }\end{array}$ & $\begin{array}{l}\text { Uang kelebihan (UK) } \\
\text { penjualan - (uang pinjaman + jasa } \\
\text { penitipan + biaya) }\end{array}$ \\
\hline $\begin{array}{l}\text { Bila dalam satu tahun uang } \\
\text { kelebihan tidak diambil maka } \\
\text { uang kelebihan tersebut menjadi } \\
\text { milik pegadaian }\end{array}$ & $\begin{array}{l}\text { Bila dalam satu tahun uang } \\
\text { kelebihan tidak ambil diserahkan } \\
\text { kepada lembaga ZIS }\end{array}$ \\
\hline
\end{tabular}

Sumber: Cholis Nafis, (2012:230).

\section{METODE}

Penelitian ini akan dilaksanakan selama 4 bulan terhitung dari juli sampai oktober 2016, penelitian ini dilaksanakan di PT. Pegadaian (Persero) Syariah Unit Tanah Merah Cabang Pegadaian Soebrantas. Jenis penelitian ini adalah kausalitas yaitu jenis penelitian yang disusun untuk meneliti kemungkinan adanya hubungan sebab akibat antara variabel. Penelitian ini bertujuan untuk mengetahui pengaruh pelayanan karyawan terhadap kepuasan nasabah.

Subjek Penelitian ini adalah nasabah yang ada pada PT. Pegadaian (Persero) Syariah dan sebagai objeknya adalah Pengaruh Pelayanan karyawan terhadap Kepuasan Nasabah pada PT. Pegadaian (Persero) Syariah Unit Tanah Merah Cabang Pegadaian Soebrantas.
Dalam penelitian ini yang dijadikan populasi adalah seluruh nasabah yang menggunakan jasa pada PT. Pegadaian (Persero) Syariah Unit Tanah Merah Cabang Pegadaian Soebrantas, 2014-2016 sejumlah 1,436 orang (Sumber PT. Pegadaian (Persero) Syariah Unit Tanah Merah Cabang Pegadaian Soebrantas. Sedangkan Sampel dari jumlah populasi di atas, maka penulis melakukan pengambilan sampel. Adapun jumlah sampel ditentukan berdasarkan rumusan Slovin dalam Muhammad (Muhammad, 2008: 180)

$n=\frac{\mathrm{N}}{1+N e 2}$

Keterangan :

$\mathrm{n}=$ Ukuran sampel

$\mathrm{N}=$ Ukuran populasi

$\mathrm{e}=$ Nilai krisis (batas ketelitian) yang diinginkan (persen kelonggaran ketidak telitian karena kesalahan penarikan sampel) 
Dalam penelitian ini jumlah populasi $(\mathrm{N})=$ 1,436 orang, dengan nilai krisis (e) sebesar $10 \%$ maka ukuran sampel.

$$
\begin{aligned}
n & =\frac{1.436}{1+(1.436)(10 \%)^{2}} \\
& =94 \text { Nasabah }
\end{aligned}
$$

Jadi dalam penelitian ini Jumlah sampelnya dibulatkan sebanyak 94 nasabah. Teknik pengambilan Sampel dalam penelitian ini adalah menggunakan randam sampling adalah cara pengambilan sampel dari anggota populasi dengan menggunakan acak tampa memperhatikan strata (tingkatan) dalam anggota populasi tersebut. Hal yang dilakukan apabila anggota populasi dianggap homogen (sejenis). Penulis mengambil sampel dari masing-masing produk yaitu Gadai Syariah, Arrum, Mulia,dan Masku.

Sumber data yang digunakan dalam penelitian ini adalah: (a) Data primer, yaitu data yang diperoleh atau dikumpulkan langsung dilokasi dan responden. Dalam penelitian ini dilakukan dengan cara meminta nasabah PT. Pegadaian (Persero) Syariah Unit Tanah Merah Cabang Pegadaian Soebrantas untuk mengisi angket. (b) Data sekunder, yaitu data yang diperoleh dari pihak perusahaan dan diperoleh dari bacaan literatur yang berkaitan dengan masalah yang diteliti.

Sedangkan teknik pengumpulan data adalah sebagai berikut: (a) Kuesioner, merupakan teknik pengumpulan data dilakukan dengan cara memberi seperangkat pertanyaan atau pernyataan tertulis kepada responden. Selain itu, angket juga cocok digunakan bila jumlah responden cukup besar dan terbesar diwilayah yang luas (Sugiyono, 2010: 142). (b) Dokumentasi yaitu pengumpulan data berupa bahanbahan dokumen dan sebagian dari PT. Pegadaian (Persero) Syariah Unit Tanah Merah Cabang Pegadaian Soebrantas, yang berkaitan dengan masalah yang diteliti.

\section{HASIL}

\section{Gambaran Umum dan Lokasi Penelitian PT. Pegadaian (Persero) Syariah Cabang Pegadaian Soebrantas}

Cabang Pegadaian Syariah Pekanbaru didirikan pada tanggal 20 Januari 2009. Cabang Pegadaian Syariah soebrantas KM 10,5 Pekanbaru pertama kali hingga saat ini terletak di Jl. HR. Subrantas KM 10,5 Pekanbaru. Perusahaan ini dipimpin oleh Ibu Netti Yusda. Produk yang dipasarkan di Cabang Pegadaian Syariah Soebrantas Panam Pekanbaru adalah produk yang berbasis syariah, yaitu Rahn (gadai syariah), Arrum (pembiayaan usaha mikro kecil), Mulia (layanan penjualan logam mulia secara tunai atau angsuran), Masku (jaminan asuransi), dan ada juga sekarang Tabungan Emas, Multi Pembayaran Online (layanan pembayaran berbagai tagihan bulanan seperti listrik, telepon, PDAM, dan lain sebagianya secara online), dan jasa titipan dan taksiaran (layanan jasa penitipan barang berharga dan jasa penaksiran karatase dan kualitas perhiasan).

Cabang Pegadaian Syariah Soebrantas Panam Pekanbaru ini memiliki kantor Unit Pelayanan Syariah (UPS) yang pertama kali didiriakn yaitu: PT. Pegadaian Syariah Unit Tanah Merah Jl. Pasir Putih.

\section{Teknik Pengolahan Data}

Teknik Pengolahan data adalah suatu proses dalam memperoleh data ringkasan atau angka ringkasan dengan menggunakan cara-cara atau rumus-rumus tertentu. Pengolahan data meliputi kegiatan berikut. (Iqbal Hasan (2010: 27) (a) Editing (penyuntingan), adalah pengecekan atau pengoreksian data yang dikumpulkan karena kemungkinan data yang masuk (rau data) atau data yang terkumpul tidak logis dan meragukan. Tujuan editing adalah untuk menghilangkan kesalahan-kesalahan yang terdapat pada pencatatan dipandangan dan bersifat koreksi. Pada kesempatan ini, kekurangan data atau kesalahan data dapat dilengkapi atau diperbaiki baik dengan pengumpulan data ulang atau pun dengan 
interpolasi (penyisipan).

(pengkodean),

(b) Coding adalah pemberian/pembuatan kode-kode pada tiaptiap data yang termasuk dalam kategori yang sama. Kode adalah isyarat yang dibuat dalam bentuk angka-angka/huruf-huruf yang memberikan petunjuk atau identitas pada suatu informasi atau data yang akan dianalisis. (c) Tabulating (Pentabulasian), adalah pembuat tabel-tabel yang berisikan data yang diberi kode sesuai dengan analisis yang dibutuhkan.

\section{Teknik Analisis Data}

Metode yang digunakan dalam penelitian ini adalah metode kuantitatif. Metode kuantitatif digunakan untuk menganalisa secara statistik guna melakukan uji penelitian terhadap data-data yang diperoleh dengan menggunakan analisis regresi linier sederhana di mana proses perhitungannya menggunakan SSPS For Windows Versi 16.0.

Angket yang digunakan dalam penelitian ini menggunakan skala lima alternatif pilihan (Skala Likert), maka terlebih dahulu data angket yang sudah berhasil dikumpulkan akan dilakukan pengujian terlebih dahulu. Pengujian yang dilakukan adalah Uji validitas, Uji Reabilitas, Analisis Regresi Linier Sederhana, Uji Parsial (Uji-t), Koefisien Korelasi, Koefisien Determinasi. (Wiratna Sujarweni, 2012: 177)

\section{Uji Validitas}

Uji validitas dilakukan dengan menggunakan rumus Corrected Item Total dengan taraf signifikan $5 \%(\alpha=0,05)$ artinya suatu item dianggap valid jika berkorelasi signifikan terhadap skor total.

Hasil penelitian terhadap indikator tiap variabel dalam penelitian ini semuanya valid. Dengan demikian valid atau tidaknya indikator tersebut, tergantung dari tanggapan responden terhadap penelitian yang penulis lakukan. Berikut hasil dari pengujian validitas untuk item-item variabel pengaruh pelayanan karyawan terhadap kepuasan nasabah pada PT. Pegadaian
(Persero) Syariah Unit Tanah Merah Cabang Pegadaian Soebrantas.

Jika $r_{\text {hitung }}>r_{\text {tabel }}$ maka item-item pertanyaan dikatakan valid. Dan jika $r_{\text {hitung }}<$ $r_{\text {tabel }}$ maka item-item dikatakan tidak valid.

Diketahui nilai $r_{\text {tabel }}$ dengan taraf signifikan 5\% $(\alpha=0,05)$ adalah sebesar 0,396 (lihat tabel r) dan nilai ini dibandingankan

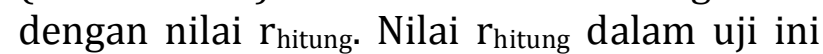
adalah pada kolom item-Total Statistics (Corrected Item- Total Correlation). Dan dari tabel di atas dapat menunjukkan bahwa butir pernyataan yang mempunyai nilai korelasi yang lebih besar dari $r_{\text {tabel, maka }}$ pernyataan tersebut dikatakan valid.

\section{Uji Reliabilitas}

Batasan nilai dalam uji reliabilitas adalah 0,6. Jika nilai reliabilitas kurang dari 0,6 maka nilainya kurang baik. Nilai reliabilitas dalam uji ini adalah pada kolom Reliability Statistics (Croanbach's Alpha).

Berdasarkan uji reliabilitas dengan menggunakan Croanbach's Alpha dapat disimpulkan bahwa 27 butir pernyataan tentang pengaruh pelayanan karyawan terhadap kepuasan nasabah pada PT. Pegadaian (Persero) Syariah Unit Tanah Merah Cabang Pegadaian Soebrantas dapat dinyatakan reliabilitas.

\section{Analisi Regresi Linier Sederhana}

Hasil perhitungan analisis regresi linier sederhana melalui SPSS for Windows versi 16.0, maka diperoleh nilai-nilai untuk variabel bebas dari variabel terikat dapat dilihat pada tabel berikut : 
Tabel 2: Analisis Regresi Linier Sederhana

\begin{tabular}{|c|c|c|c|c|}
\hline \multirow{2}{*}{\multicolumn{2}{|c|}{ Model }} & \multicolumn{2}{|c|}{ Unstandardized Coefficients } & \multirow{2}{*}{$\begin{array}{c}\begin{array}{c}\text { Standardized } \\
\text { Coefficients }\end{array} \\
\text { Beta }\end{array}$} \\
\hline & & B & Std. Error & \\
\hline \multirow[t]{2}{*}{1} & (Constant) & 7.086 & 3.875 & \\
\hline & Pelayanan & .768 & .067 & .766 \\
\hline
\end{tabular}

Sumber: Data Olahan SPSS Versi 16.0

Berdasarkan tabel di atas, maka dapat disusun persamaan regresi linier sederhana sebagai berikut:

$$
\begin{aligned}
& Y=a+b X \\
& Y=7,086+0,768 X
\end{aligned}
$$

Arti angka-angka dalam persamaan regresi linier sederhana di atas adalah:

1) Nilai $\mathrm{a}=7,086$ menunjukkan bahwa apabila nilai variabel $X=0$, maka nilai variabel Y sebesar 7,086.

2) Nilai $b=0,768$, menunjukkan bahwa apabila nilai variabel pelayanan karyawan (X) menurun satu-satuan, maka variabel kepuasan nasabah (Y) akan mengalami penurunan sebesar 0,768 satuan dengan asumsi variabel $\mathrm{X}$ tetap atau konsisten.

\section{Uji-t (Uji Parsial)}

Uji-t dapat dilakukan untuk melihat bagaimana pengaruh masing-masing variabel, yaitu variabel bebas dan variabel terikat dengan menggunakan Uji-t (Uji Parsial) dengan menggunakan bantuan program SPSS for Windows versi 16.0, maka hasil uji t dapat dilihat tabel berikut ini:

\begin{tabular}{|c|c|c|c|c|c|}
\hline \multirow[b]{2}{*}{ Model } & \multicolumn{2}{|c|}{$\begin{array}{l}\text { Unstandardized } \\
\text { Coefficients }\end{array}$} & $\begin{array}{c}\text { Standardize } \\
\mathrm{d} \\
\text { Coefficients }\end{array}$ & \multirow[b]{2}{*}{ l } & \multirow[b]{2}{*}{ Sig. } \\
\hline & B & Std. Error & Beta & & \\
\hline $1 \quad$ (Constant) & 7.086 & 3.875 & & 1.829 & .071 \\
\hline $\mathrm{X}$ & .768 & .067 & .766 & 11.417 & .000 \\
\hline
\end{tabular}

Tabel 3. Perhitungan Uji-t

Sumber: Data Olahan SPSS Versi 16.0

Dari pengolahan tabel di atas, dapat diketahui bahwa nilai thitung variabel pelayanan karyawan (X) sebersar 11.417 dan nilai $t_{\text {tabel }}$ sebesar 1,658 dengan tingkat signifikan sebesar 0,05 dan derajat kebebasan sebesar 93 (dk=n-1 (94-1)) maka terlihat bahwa : $t_{\text {hitung }}>t_{\text {tabel }}$ atau $11.417>$ 1,658. Hal ini menunjukkan bahwa $\mathrm{Ha}$ diterima dan Ho ditolak, sehingga dapat dikatakan terdapat pengaruh signifikan antara pelayanan karyawan terhadap kepuasan nasabah.

\section{Koefisien Korelasi}

Koefisien korelasi berfungsi untuk melihat kuat atau lemahnya hubungan antara variabel bebas terhadap variabel terikat. Untuk mengetahui hal tersebut, maka digunakan koefisien korelasi dengan menggunakan bantuan program SPSS for Windows versi 16.0 dan hasilnya dapat dilihat pada tabel berikut ini : 
Tabel 4: Analisis Korelasi

\begin{tabular}{|l|l|r|r|r|}
\hline Model & R & R Square & $\begin{array}{c}\text { Adjusted R } \\
\text { Square }\end{array}$ & $\begin{array}{c}\text { Std. Error of the } \\
\text { Estimate }\end{array}$ \\
\hline 1 & $.766^{\mathrm{a}}$ & .586 & .582 & 3.968 \\
\hline
\end{tabular}

a. Predictors: (Constant), $\mathrm{X}$

Dari pengolahan tabel di atas diketahui bahwa nilai $\mathrm{R}$ menunjukkan korelasi antara variabel independen dengan variabel dependen. Diketahui nilai R sebesar 0.766 atau $76,6 \%$. Artinya adalah bahwa korelasi antara variabel pelayanan karyawan dengan variabel kepuasan nasabah (studi kasus PT. Pegadaian (Persero) Syariah Unit Tanah Merah Cabang Pegadaian Soebrantas adalah kuat.

\section{Koefisiein Determinasi}

Sedangkan untuk melihat besarnya kontribusi variabel $\mathrm{X}$ terhadap variabel $\mathrm{Y}$ digunakan uji koefisien determinasi. Koefisien determinasi $\left(\mathrm{R}^{2}\right)$ adalah besaran yang mengajukan sebesarap besar perubahan variabel terikat $(\mathrm{Y})$ yang dapat dipegaruhi oleh variabel bebas (X).

Diketahui nilai $\mathrm{R}$ Square sebesar 0,586 . Artinya bahwa kontribusi pengaruh variabel independen $(\mathrm{X})$ terhadap variabel dependen (Y) adalah sebesar 58,6\%. Sedangkan sisanya $41,4 \%$ dipengaruhi oleh variabel lain yang tidak dimasukkan dalam penelitian ini.

\section{PEMBAHASAN}

$$
\text { Penelitian tentang Pengaruh }
$$

Pelayanan Karyawan Terhadap Kepuasan Nasabah pada PT. Pegadaian (Persero) Syariah Unit Tanah Merah Cabang pegadaian soebrantas terdiri dari dua variabel yaitu variabel bebas (pelayanan karyawan) dan variabel terikat (kepuasan nasabah).

Analisis data yang digunakan dalam penelitian ini adalah metode deskriptif kuantitatif yaitu menganasisa data secara argumentasi dan menganalisa data secara statistik dengan mengunakan analisis regresi linier sederhana yaitu untuk mengukur

pengaruh antara variabel bebas (pelayanan karyawan) terhadap variabel terikat (kepuasan nasabah) dengan proses perhitungan data mengunakan program SPSS versi 16.0

Dari hasil diatas pertama penulis melakukan pengujian signifikan atau uji persial antara pelayanan karyawan terhadap kepuasan nasabah, dimana pengujian ini dilakukan untuk mengetahui pengaruh antara pelayanan karyawan terhadap kepuasan nasabah. Hasil pengujian diketahui bahwa terdapat pengaruh yang signifikan antara pelayanan karyawan terhadap kepuasan nasabah pada PT. Pegadaian (persero) Syariah Unit Tanah Merah Cabang Pegadaian Soebrantas, ini diketahui dari nilai thitung (11.417) lebih besar dari $t_{\text {tabel }}$ $(1,658)$. Ini berarti secara parsial dapat diketahui bahwa variabel $\mathrm{X}$ (pelayanan karyawan) terdapat pengaruh terhadap variabel Y (kepuasan nasabah).

Kemudian pengujian koefisien korelasi, dimana koefisien korelasi merupakan bentuk nilai yang diguankan untuk menentukan jenis korelasi (hubungan) antara pelayanan karyawan terhadap kepuasan nasabah. Berdasarkan hasil perhitungan koefisien korelasi diatas diketahui bahwah besarnya koefisien korelasi antara pelayanan karyawan terhadap kepuasan nasabah (R) 76,6\%, ini berarti bahwa hubungan antara pengaruh pelayanan karyawan terhadap kepuasan nasabah (studi kasus PT. Pegadaian (persero) Syariah Unit Tanah Merah Cabang Pegadaian Soebrantas adalah kuat.

Setelah itu penulis melakukan analisis koefisien determinasi, dimana koefisien determinasi merupakan besaran yang menunjukan seberapa kontribusi 
pengaruh variabel X (pelayanan karyawan) terhadap variabel Y (kepuasan nasabah). Dari hasil analisis diketahui besaran nilai kontribusi koefisien determinasi antara pelayanan karyawan terhadap kepuasan nasabah sebesar 58,6 \% dan sisanya 41,4\% dipengaruhi oleh variabel lain yang tidak dimasukkan dalam penelitian ini.

\section{SIMPULAN}

Berdasarkan hasil pembahasan yang di uraikan pada bab-bab terdahulu tentang pengaruh pelayanan karyawan terhadap kepuasan nasabah pada PT. Pegadaian (Persero) Syariah Unit Tanah Merah Cabang Pegadaian Soebrantas, maka penulis dapat menyusun beberapa kesimpulan sebagai berikut: (1) Berdasarkan Hasil Penelitian Pangruh Pelayanan Karyawan terhadap Kepuasan Nasabah PT. Pegadaian (Persero) Syariah Unit Tanah Merah Cabang Pegadaian Soebrantas hubungan yang kuat. (2) Berdasarkan hasil perhitungan uji-t dari semua variabel $\mathrm{X}$ yang berpengaruh paling dominan adalah pengaruh kepuasan nasabah $\left(\mathrm{X}_{2}\right)$ dan di ikuti oleh pengaruh lainnya yaitu pengaruh pelayana karyawan pada PT. Pegadaian (Persero) Syariah Unit Tanah Merah Cabang Pegadaian Soebrantas, diketahui hasil dari koefisien determinasi kontribusi variabel bebas terhadap variabel terikat besar Sedangkan sisanya dipengaruhi oleh variabel lain, sedangkan pengruh lain yang tidak diikutsertakan dalam penelitian pengaruhnya kecel. Hal ini dapat dilihat dari nilai koefision korelasi sederhana,

\section{DAFTAR RUJUKAN}

Arif, M. (2018). ANALISIS REKRUTMEN DAN PENEMPATAN KERJA TERHADAP KINERJA KARYAWAN PADA HOTEL OASE. Al-Hikmah: Jurnal Agama Dan Ilmu Pengetahuan, 15(1), 42-63. doi:10.25299/jaip.2018.vol15(1).1584

Andri Soemitra, Bank dan Lembaga Keuangan Syariah, Jakarta, Kencana, 2010.
Andrian Sutedi, Aspek Hukum Pengadaan Barang dan Jasa, jakarta, Sinar Grafika, 2009

Anwar Sanusi, Metode Penelitian Bisnis, Malang, Salemba Empat, 2011.

Ahmad, Kinerja Karyawan dalam Melayani Nasabah Pada PT. Pegadaian Syariah

Unit Pandau Permai Cabang Soebrantas, Skripsi, Program Studi Ekonomi Islam, 2015.

Rino Desanto W, Pengaruh Kualitas Pelayanan dan kepuasan konsumen terhadap Intensi Hunian Ulang Hotel Merdeka Medium, Skripsi, Program Studi EkonomiSyariah, 2008.

Ahmad Rodoni, Asuaransi dan Pegadaian syariah, Jakarta, Mitra Wahana Media, 2015.

Cholis Nafis, Mengenal Pegadaian Syariah, Jakarta, Bambu Wulong,2012.

Departemen Pendidikan Nasional, Kamus Besar Bahasa Indonesia, Jakarta, Gramedia Pustaka Utama, 2008.

Jhon M.Echois et al, Kamus Bahasa Indonesia dan Bahasa Inggris, Jakarta, PT Gramedia, 2010

Daryanto, Konsumen dan Pelayanan Prima, Yogyakarta, Gava Media, 2014.

Edy Sutrisno, Manajemen Sumber Daya Manusia, Jakarta, Prenada Media Group, 2009.

Fakultas Agama Islam, Panduan skripsi, Pekanbaru. 2012.

Husaini Usman dan Purnomo Setiady Akbar, Pengantar Statistika, jakarta, PT. Bumi Aksara, 2008.

Kasmir, Kewirausahaan, Jakarta, PT. Raja Grafindo Persada, 2006.

Nina Rahmayanty, Manajemen Pelayanan Prima, Graha Ilmu, 2010.

Nur Rianto Al Arif, Dasar-dasar Pemasaran Bank Syariah, Bandung, Alfabeta, 2010.

Malayu S.P. Hasibuan, Manajemen Sumber Daya Manusia, Jakarta, PT. Bumi Aksara, 2009. 
Mardani, Ayat-ayat dan Hadist Ekonomi Syariah, Jakarta, PT. Raja Grafindo Persada, 2011.

Musbahuddin Dan Iqbal Hasan, Analisis Data Penelitian Dengan Statistik, PT. Bumi Aksara, 2013.

Muhammad, Metode Penelitian Ekonomi Islam Pendekatan Kuantitatif, Jakarta, Raja Grafindo Persada, 2008..

Mustafa Edwin Nasution, Pengenalan Ekslusif Ekonomi Islam, Jakarta, Kencana, 2006.

Ratminto, Manajemen Pelayanan, Yogyakarta, Pustaka Pelajar, 2005.

Riduwan, Dasar-dasar Statistik, Bandung, Alfabeta,2009.

Ridwan dan Engkos, Cara Menggunakan dan Analisis Jalur (Path Analysis), Bandung, Alfabeta, 2007.

Santot ImamWahjono, Manajemen Pemasaran Bank, Surabaya, Graha Ilmu, 2009.

Sugiyono, Metode Penelitian Kuantitatif dan Kualitatif R\&D, Alfabeta, Bandung, 2010.

Riduwan dan Sunarto, Pengantar Statistik, Jakarta, Alfabeta, 2011
Wiratna Sujarweni dan Poly Endrayanto, Statistik Untuk Penelitian, Yogyakarta, Graha Ilmu

Zainuddin Ali, Hukum Gadai Syariah, Jakarta, Sinar Grafika, 2008. 